Research Article/Araştırma Makalesi

\title{
Do Teachers Behave Ethically? Investigation of Teachers' Perceptions about their Colleagues
}

\author{
Gürkan SARIDAŞ *1 (D) Özen YILDIRIM ${ }^{2}$ \\ ${ }^{1}$ Ministry of Education, Denizli, Turkey, theapeiron@gmail.com \\ ${ }_{2}^{2}$ Pamukkale University, Faculty of Education, Denizli, Turkey, ozenyildirim@pau.edu.tr \\ ${ }^{*}$ Corresponding Author: ozenyildirim@pau.edu.tr
}

Article Info

Received: 13 September 2019

Accepted: 16 October 2019

Keywords: Professional ethics, ethics in teaching profession, scale development

DOI: $10.18009 /$ jcer.619439

Publication Language: Turkish

\begin{abstract}
Professional ethical behaviors of the teacher are important for the development of the student in every aspect who are taking role model of their teachers. Within the scope of the research, it was aimed to develop a valid and reliable scale. The sample of the study consists of 394 secondary school teachers working in Denizli province Turkey. In addition, data were collected from 276 secondary school teachers for the confirmatory factor analysis. Data were analyzed by using principal components analysis, confirmatory factor analysis and other reliability evidences. Descriptive statistics, independent samples t-test and oneway ANOVA analysis were used to determine the differences between their perceptions. According to the results of the study, the valid and reliable scale with a one-dimensional structure was developed. When teachers' perceptions are examined, the majority of them think that their colleagues behave ethically inside and outside the school. It was also determined that these perceptions differ according to gender and seniority.
\end{abstract}

To cite this article: Sarıdaş, G., \& Yıldırım, Ö. (2019). Öğretmenler etik davranıyor mu? öğretmenlerin meslektaşları hakkındaki algılarının incelenmesi. Journal of Computer and Education Research, 7(14), 621-641. DOI: 10.18009/jcer.619439

\section{Öğretmenler Etik Davranıyor mu? Öğretmenlerin Meslektaşları Hakkındaki Algılarının İncelenmesi}

\begin{tabular}{|c|c|}
\hline Makale Bilgisi & Öz \\
\hline & Öğretmenin mesleki etik davranması kendisini rol model alan \\
\hline & öğrencinin her yönden gelişimi için önemlidir. Araştırma kapsamında \\
\hline & geçerli ve güvenilir bir ölçek geliştirilmesi amaçlanmıştır. Araştırmanın \\
\hline 13 Eylul 2019 & örneklemini Denizli ilinde görev yapan 394 ortaokul öğretmeni \\
\hline 10 LКLI $\angle 019$ & oluşturmaktadır. Ayrıca ölçeğin doğrulayıcı faktör analizi için 276 \\
\hline & kişilik ortaokul öğretmeninden veri toplanmıştır. Verilerin analizinde \\
\hline Anahtar kelimeler: Mesleki etik, & temel bileşenler analizi, doğrulayıcı faktör analizi kullanılmış ve diğer \\
\hline öğretmenlik mesleğinde etik, ölçek & güvenirlik kanıtları hesaplanmıştır. Öğretmenlerin algıları arasındaki \\
\hline geliştirme & farklılaşmayı ortaya koymak için betimsel istatistiklerden, bağımsız \\
\hline & örneklemler t-testi ve tek yönlü ANOVA analizinden yararlanılmıştır. \\
\hline DOI: 10.18009/jcer.619439 & Araştırmanın sonuçlarına göre tek boyutlu bir yapıya sahip geçerli ve \\
\hline & güvenilir bir ölçek geliştirilmiştir. Öğretmenlerin algıları, \\
\hline Yayım Dili: Türkçe & meslektaşlarının okul içinde ve dışında etik davrandığı yönündedir. \\
\hline & Ayrıca bu algıların cinsiyete ve kıdeme göre farklılaştığı belirlenmiştir. \\
\hline
\end{tabular}




\section{Summary}

\section{Do Teachers Behave Ethically? Investigation of Teachers' Perceptions about their Colleagues}

\section{Introduction}

Teachers tend to exhibit different behaviors within accepted professional rules while performing various tasks, roles and responsibilities. Teacher's behaviors are evaluated as good, bad, right and wrong within the framework of ethics. The teacher, who is a role model for his / her students, is expected to exhibit his / her behaviors in a way that can be described as good and correct. Behaviors that teachers should do or should not do were determined as professional ethical codes. It is ensured that unethical behaviors are not exhibited through ethical codes. In the study, the teachers' professional ethics perception scale was developed and the differences between the perceptions according to teacher characteristics (gender, seniority) were examined.

\section{Method}

The research was conducted on 510 secondary school teachers working in the central districts of Denizli Turkey. Criterion sampling was used in the sample selection. As a criterion, five years in the profession requirement was sought. Teachers were reached from selected schools by cluster sampling method. In the scale development stage, validity analyzes based on Principal Component Analysis and Confirmatory Factor Analysis were performed and the internal consistency of the scale was calculated with Cronbach alpha. In addition, evidence was obtained for validity and reliability by looking at the group analysis of the item analysis and item total test correlations. Teachers' perceptions were tested with descriptive statistics and differences between their perceptions by independent samples $\mathrm{t}$ test and One Way ANOVA analysis. 


\section{Results}

The one factor scale, which was designed to measure teachers' perceptions about their colleague's' professional ethics, explains almost half (42\%) of the structure. According to the item total test correlation results for the validity and reliability of the scale, each item has a high correlation value on a 13-item scale. It was also observed that they were able to distinguish the upper and lower groups sufficiently. The Cronbach Alpha value, which provides information about the internal consistency of the scale, is quite high. In order to confirm the structure, DFA analysis was performed using a different sample, and the 11-item scale confirmed the structure according to the calculated goodness of fit values.

On the other hand, teachers' perceptions about their colleagues' professional ethics were high. There is a significant difference between them according to gender. The average of female teachers is higher than the average of male teachers. A significant difference was also found among seniority variables. Low-seniority level teachers think that their colleagues' ethical behaviors are lower when compared to high seniority-level teachers.

\section{Discussion and Conclusion}

The scale measures various ethical perceptions of teacher about the responsibilities of the teacher based on ethical behaviors in education towards himself and the student, his professional development, the transfer of national and universal values, and his responsibilities towards the family and society. The scales used in the literature for this purpose generally focus on a specific subject of ethics. The improved scale includes a broad scope. It is desirable for teachers to have a high level of professional ethics perceptions about their colleagues, to develop the educational environment and to enable students to study in an appropriate educational environment. In many studies, it was found that teachers behave ethically. The reason why female teachers have higher professional perceptions of their colleagues than male teachers can be related to their being more sensitive, more optimistic and more flexible. Low seniority level of teachers' perceptions of ethical behaviors of their colleagues differs when compare with high-seniority level teachers. This is because Low seniority level of teachers may be more likely to be more enthusiastic and idealistic in the first years of their profession. Also young teachers may have high expectations from teachers who are around them. 


\section{Giriş}

Okul içinde öğretmenin sorumlulukları sadece eğitim öğretim faaliyetlerini yerine getirmek ile sınırlı olmamakla birlikte öğretmenlere çeşitli roller ve sorumluluklar yüklenmektedir. Öğretmenin öğretim sürecindeki başarısı veya başarısızlığı bu görev, sorumluluk ve rolleri kullanma gücü ile ilişkili bir durumdur (Sünbül, 1996). Bu noktada öğretmenlerin okul içinde veya dışında aldıkları rol, görev ve sorumlulukları kullanırken ortaya koydukları davranışlar önem kazanmaktadır. Bu davranışların kabul görmüş mesleki kurallar dâhilinde olması beklenir.

Geçmişten günümüze kadar düşünürler insanların davranışlarına yönelik atfedilen kavramları tartışmış ve belirli kurallar dâhilinde ortaya konulan davranışları etik çatısı altında toplamışlardır (Erdem \& Altunsaray, 2016). Öğretmenlerin okul içinde ve dışındaki davranışlarının iyi, kötü, doğru veya yanlış olarak değerlendirilmesi etik, bir diğer ifadeyle ahlak felsefesi kapsamına girer. Ahlak felsefesi geniş bir tanımlama iken etik daha dardır. Etik ile ilgili bir tanım yapmak gerekirse ahlaki ölçütlerden yararlanarak sergilenen davranışlara yön verilmesi, kabul edilmiş değerler temelinde standartlaştırılmasıdır (Key \& Popkin). Genel olarak etik; ahlak çerçevesinden davranışların değerlendirilmesidir. Bu değerlendirme kişi özelinde olduğu için etik anlayışta tek taraflılık vardır ve sergilenen davranışın değerlendirilmesi sonucu sadece davranışı sergileyen bireyin sorumluluğundadır. Birey, etik değerler çerçevesinde bu standartlaşmanın dışına çıkmamaya çalışır. İyi ve doğru olanı yapmaya eğilimli davranış sergiler (Ilgaz \& Bilgili, 2006).

Etik ile ilgili temellerin oluşturulmasında belirli yaklaşımlar bulunmaktadır. Bunlar; yararcı yaklaşım, hak yaklaşımı, iyilik ve adalet yaklaşımı, herkesin iyiliği yaklaşımı ve değer yaklaşımıdır (Santa Clara University, 2015). Bu yaklaşımlarla birlikte belirli temellere dayandırılarak (kozmolojik temellendirme, teolojik temellendirme, antropolojik temellendirme ve sosyolojik temellendirme) etik değerler belirlenmeye çalışılmaktadır. Yaklaşım ve temellendirmeler çerçevesinde etik; betimleyici etik, normatif etik ve meta etik olmak üzere üç ayrı türe ayrılabilir (Cevizci, 2002). Her ne kadar etik çeşitlendirilmiş olsa da yaklaşımların/temellerin tamamı eğitim öğretim faaliyetleri içinde bulunmaktadır. $\mathrm{Bu}$ yüzden eğitim öğretim faaliyetleri içerisinde belirli bir yaklaşımı, temeli veya çeşidi almak 
mümkün değildir. Bu da öğretmen davranışlarının belirli bir çerçevede sınırlandırılamadığı anlamina gelir.

Öğrenciler ile sürekli etkileşim halinde bulunan öğretmenlerin, kendi kişiliklerini oluşturma sürecinde öğrencilere rol model olması, onların kendilerini daha iyi tanımasını sağlaması ve eğitim öğretim faaliyetlerini gerçekleştirmesi sürecinde davranışlarını iyi veya doğru olarak tanımlanabilecek şekilde sergilemesi beklenmektedir. Bu da etik davranışların eğitim içindeki önemine işaret etmektedir. Örneğin öğrencilerine karşı adil ve eşit davranan bir öğretmenin yetiştirdiği öğrencilerin öğretmenini rol model alarak benzer davranışları kazanması beklenir. Bu ve benzeri etik kuralların uygulanması genel çerçevede okulun doğru davranışların kazandırıldığı bir merkez olduğu anlamına gelir.

Öğretmenlerin etik sözleşmesi ilk olarak öğretmen andında karşımıza çıkmaktadır. Öğretmenler, göreve başlamadan bu yemini sözlü olarak ifade ederler. Öğretmenlerin, meslek standartları kapsamında belirlenen davranışları uyguluyor olmasının yanında içselleştirmesi de beklenir. Bu içselleştirme öğretmenin hayatında etik kuralları uygulaması anlamına gelmektedir. Öğretmenin görevini etkili ve doğru yapabilmesi, "İyi Öğretmen” olarak nitelendirilebilmesi, diğer meslek gruplarından ayrılan değerlerin belirlenebilmesi ve bu değerlere göre değerlendirilebilmesine gereksinim bulunmaktadır (Tunca \& Sağlam, 2013). Bu gereksinim mesleki etik kodların ortaya çıkmasına neden olmaktadır. Öğretmenlerin mesleki etik kodları çeşitli yönetim kademelerince belirlenmektedir (Fisher, 2013). Etik kodlar, öğretmenlerin davranışlarının iyi veya doğru olarak nitelendirilmiş halleridir. Bu kodlar kapsamında öğretmenlerin davranışlarının etik kurallar dâhilinde olup olmadıkları anlaşılabilmektedir.

Öğretmenlik mesleği etik kodları, öğretmenlerin yapması gereken davranışların yanı sıra yapmaması gereken davranışları da içermektedir. Bunlar öğrenciye yönelik davranışlar, sınıf içinde sergilenen davranışlar, okul içinde sergilenen davranışlar, okul sınırları dışında sergilenen davranışlar ve kendisi ve diğer meslektaşlarına yönelik davranışlar olarak gözlenmiştir (Altınkurt \& Yılmaz, 2011; Sünbül, 1996). Bu davranışlar; öğrenciye yönelik, öğrenme öğretme süreciyle ilgili, öğretmenin milli ve evrensel değerleri ile ilgili, öğretmenin mesleki gelişimi ile ilgili ve aile, okul ve toplum ilişkisi ile ilgili etik davranışlar olmak üzere toplam beş alanda toplanabilir. Eğitim öğretim faaliyetlerini düzenleyen, yönetimini gerçekleştiren, öğrencilere etkili rol model olan, çeşitli rol ve sorumlulukları ile toplumsal ilerlemede önemli bir göreve sahip olan öğretmenin diğer meslek gruplarından farklı olarak 
etik kurallara daha uygun davranması önem taşımaktadır. Bu önem nedeniyle var olan öğretmen davranışlarının belirlenmesi ve olabilecek etik dışı davranışların önüne geçilmesi gerekmektedir.

$\mathrm{Bu}$ çalışma kapsamında öğretmenlerin mesleki etik algılarını ortaya koymak için öğretmenin tüm rol, görev sorumluluklarını kapsamak amacıyla içerik genişletilerek, öğretmenin kendine ve öğrenciye yönelik sorumluluklarının yanı sıra öğretmenin mesleki gelişimi, milli ve evrensel değerlerin aktarımı ile aile ve topluma karşı sorumlulukları incelenmiştir. Bu amaçla öğretmenlerin meslektaşlarını değerlendirebileceği mesleki etik algıları ölçeği geliştirilmiş ve öğretmen özelliklerine (cinsiyet, kıdem) göre algıları arasındaki farklar ortaya konulmaya çalışılmıştır. Öğretmenlerin meslektaşları hakkındaki etik algılarının değişebileceği düşünülen iki farklı değişken (cinsiyet, kıdem) seçilmiştir. Bu seçim öğretmenleri birbirinden ayıran ve farklı bir algıya sahip olabilecekleri gruplandırmalardır. Alan yazın incelendiğinde öğretmenlerin etik değerlerini ölçmek amacıyla ölçek geliştirilmiş olsa da bu ölçeklerin içerik olarak öğretmenle ilişkili olabilecek farklı özelliklere dayalı hazırlanmadığı görülmektedir. Bunlar çoğunlukla öğrenciye ve öğretmenin kendi sorumluluklarına dayalı geliştirilen ölçeklerdir. Bu ölçekler öğrenciye yönelik, öğrenme öğretme sürecine yönelik ve öğretmenin kişisel değerlerine yönelik boyutlarda ölçülmüştür (Aydın, 2018; Erdem \& Altunsaray, 2016; Ilgaz \& Bilgili, 2006; Millî Eğitim Bakanlığı, 2005). Ayrıca bu ölçeklerin hepsinde öğretmenler kendi davranışlarını değerlendirmekte, geliştirilen ölçekte ise ikinci bir göz olarak meslektaşlarını değerlendirmeleri istenmektedir. Alan yazında bu amaçla istenilen özelliği ölçen bir ölçeğe ise rastlanmamıştır.

\section{Yöntem}

\section{Araştırmanın Modeli}

$\mathrm{Bu}$ araştırmada öğretmenlerin meslektaşları hakkındaki etik davranma algılarını belirlemek için bir ölçek geliştirmek ve bu algıların öğretmenle ilgili değişkenler bakımından nasıl farklılaştığını ortaya koymak amaçlanmıştır. Çalışma, ölçek geliştirme yönü ile temel bir araştırma, öğretmenlerin algıları arasındaki farklılaşmaları ortaya koyması açısından da karşılaştırma türü bir tarama modelidir. Tarama modelleri evren hakkında genel bir yargıya varmak amacıyla evrenin tümü ya da ondan alınacak bir grup üzerinden verinin toplanarak olduğu gibi yansıtıldığı araştırmaları kapsar (Karasar, 2000). 


\section{Çalışma Grubu}

Çalışma grubunun seçiminde araştırmanın amacına dayalı olarak, öğretmenlerin örnekleme girmesi için bir ölçüt belirlenmiştir. Ölçüt olarak hizmette beş yıl şartı aranmış ve araştırmaya meslekte beş yıl ve üzeri kıdeme sahip öğretmenler katılmıştır. Bakioğlu (1996)'na göre öğretmenlik kariyer evrelerinden ilk beş yıl kariyere giriş evresi olarak belirlenmiş ve bu evrede öğretmenin öğretim programı, pedagoji ve sınıf yönetimi bilgisi öğretmene değil, tamamen okul kültürüne bağlı olarak değişmektedir. $\mathrm{Bu}$ evrede öğretmenler kendini geliştirirken bir yandan da sosyalleşmeye başlamaktadırlar. Beşinci yıldan sonra öğretmenler durulma evresine geçmekte ve bu evrede kendilerini tecrübeli olarak kabul etmektedir. $\mathrm{Bu}$ dönemden itibaren öğretmenler ustalık kazanmaya başlamaktadır. Araştırmada öğretmenlerin mesleğe yönelik etik eğilimleri ve bu konudaki meslektaşlarına yönelik gözlemlerinin doğruluğunun beş yıldan sonra daha belirgin ortaya çıkacağı varsayılmıştır. Bu nedenle çalışmamızda mesleki kıdem olarak beş yıl şartı aranmıştır.

Çalışma grubu küme örnekleme yöntemi kullanılarak rastgele seçilen Pamukkale ilçesinden toplam yedi resmi ortaokuldan 267 öğretmen, Merkezefendi ilçesinden altı resmi ortaokuldan 243 öğretmen olmak üzere toplam beş yıl ve üzeri kıdeme sahip 510 öğretmene ulaşılmıştır. Anketlerin yanıtlanma durumu ve analize uygun uç değerlerin çıkarılmasının sonucunda 394 kişilik çalışma grubu üzerinde çalışılmıştır. Çalışma grubuna ait cinsiyet, yaş ve kıdeme dayalı betimsel istatistikler Tablo 1'de verilmiştir.

Tablo 1. Çalışma grubuna ait cinsiyet, yaş, kıdem dağılımı

\begin{tabular}{llcc}
\hline \multirow{3}{*}{ Cinsiyet } & Kadın & 193 & 49.00 \\
\cline { 2 - 4 } & Erkek & 201 & 51.00 \\
\cline { 2 - 4 } Yaş & 28-35 Yaş arası & 105 & 26.60 \\
& 36-45 Yaş arası & 176 & 44.70 \\
& 46 Yaş ve üzeri & 113 & 28.70 \\
\hline \multirow{3}{*}{ Kıdem } & 5-10 Yıll arası & 80 & 20.00 \\
& 11-15 Yil arası & 93 & 23.60 \\
& 16-20 Yil arası & 110 & 27.90 \\
& 20 Yıl üzeri & 111 & 28.20 \\
\hline Toplam & & 394 & 100.00 \\
\hline
\end{tabular}

Çalışma grubunun cinsiyete göre dağılımı incelendiğinde \%49'u (f=193) kadın, \%51'i $(\mathrm{f}=201)$ erkektir. Bu durum erkek ve kadın katılımcı sayısının birbirine yakın olduğunu ortaya koymaktadır. Yaş dağılımına bakıldığında, \%26.60'1 (f=105) 28-35 yaş arasında, 
\%44.70'i ( $\mathrm{f}=176$ ) 36-45 yaş arasında, \%28.70'i ( $\mathrm{f}=113$ ) 46 yaş ve üzerindedir. 28-35 ve 46 yaş üzeri öğretmenlerin yüzdesi birbirine yakınken, dağılımda 36-45 yaş üstündeki öğretmenlerin sayısı daha fazladır. Öğretmenlerin kıdemleri incelendiğinde ise \%20'si (f=80) 6-10 yıl arasinda, \%23.60'1 ( $\mathrm{f}=93$ ) 11-15 yıl arasinda, \%27.90' 1 ( $\mathrm{f}=110)$ 16-20 yıl arasinda ve \%28.20'si (f=111) 20 yıl üzeri kıdeme sahiptir. Çalışma grubunda öğretmenler kıdem düzeylerine göre benzer dağılıma sahiptir.

\section{Verilerin Toplanması}

Araştırmanın amacı doğrultusunda öğretmenlerin meslektaşları hakkındaki etik davranma algıları hakkında bilgi toplamak için veri toplama aracı, araştırmacılar tarafından geliştirilmiştir. Ölçme aracının geliştirilmesinde öncelikle alan yazın ve bu alanda geliştirilen ölçekler detaylı bir şekilde incelenmiştir (Altınkurt \& Yılmaz, 2011; Aydın, 2018; Barrett, Casey, Visser \& Headley, 2012; Fisher, 2013; Key \& Popkin, 1998; Manolova, 2011; Xie, 2014). Daha sonra ortaokulda görev yapan altı öğretmenle okul ortamında etik eğilimlere dayalı “Siz bir öğretmenin mesleki olarak etik davrandığını hangi davranışlarından anlarsınız?" şeklinde madde sorulmuştur. Yüz yüze görüşmelerin ardından alınan notlar incelenmiştir.

Alan yazın ve görüşmelerin incelenmesinin ardından öğretmenlerin meslektaşlarına yönelik etik davranma algılarını ölçmek üzere beş başlık belirlenmiştir. Bunlar “öğrenci, öğrenme ve öğretme süreci, milli ve manevi değerler, mesleki gelişim, okul, aile ve toplum ilişkisi" dir. $\mathrm{Bu}$ özellikler dikkate alınarak öğretmenlerin meslektaşları hakkındaki etik eğilim davranışlarına yönelik düşüncelerini ortaya çıkarmak için 37 maddelik beşli likert türü (dereceli) bir ölçek oluşturulmuştur. Ölçekte bulunan 37 maddenin dokuzu öğrenciye, yedisi öğrenme öğretme sürecine, yedisi milli ve manevi değerlere, yedisi mesleki gelişime, yedisi okul, aile ve toplum ilişkisine dayalı meslektaşlarının etik davranış eğilimlerini ölçmek amacıyla hazırlanmıştır. Ölçekteki her bir madde "hiçbir zaman, nadiren, ara sıra, çoğunlukla ve her zaman" şeklinde derecelenmiştir. Ölçek maddelerinin öğretmenlik eğitimi alanında mesleki etik dersleri veren alan uzmanı dört kişi, ölçme ve değerlendirme uzmanı üç kişi ve dil uzmanı dört kişi tarafından akıcılık, anlaşılırlık, istenilen özelliğin ölçülebilme durumları bakımından uygunluk derecesi belirlenmeye çalışılmış, alınan dönütler sonrasında maddeler düzenlenmiş ve pilot uygulamaya 22 madde alınmıştır.

Hazırlanan ölçeğin yanı sıra, öğretmenlerin demografik özelliklerini ve etik davranışları genel olarak ölçen toplam beş maddeden oluşan bir anket geliştirilmiştir. 
Ankette yer alan ilk dört maddeyle öğretmenlerin cinsiyet, yaş, kıdem ve branşı hakkında bilgi toplanırken, diğer madde beş alt madde içermekte ve öğretmenlerin gözlemlerine göre “öğrenciye, öğrenme-öğretme sürecine, milli ve manevi değerlere, mesleki gelişimine ve okul, aile ve toplum üçlüsü" ne yönelik meslektaşlarını etik davranışlar bakımından beşli likert tarzda değerlendirmesi istenmiştir. Bu anket, ölçekle birlikte yukarıda belirtilen uzmanlara verilmiş ve uzmanların önerileri doğrultusunda düzenlenmiştir. Bu sayede ölçeğin ve anketin uzman görüşlerine göre kapsam geçerliği sağlanmıştır.

\section{Verilerin Analizi}

Araştırmanın ilk amacına dayalı olarak ölçeğin yapısını ortaya koymak ve maddeleri azaltmak amacıyla temel bileşenler analizi yapılmıştır. Bu amaçla 510 öğretmenden elde edilen veriler kayıp veri ve aykırı değerlerler bakımından incelenmiş ve son durumda 394 öğretmen ait veriler üzerinden analizler yürütülmüştür. Korelasyon matrisi oluşturularak 22 madde arasında çoklu bağlantı problemine bakılmış bu amaçla kesme noktası 0.80 alınmıştır (Tabachnick ve Fidell, 2013). Ancak bu sorunla karşılaşılmamıştır. Daha sonra verilerin dağılımı incelenmiştir. Verilerin ortalama (111.80), mod (109.0) ve medyan (112.0) değerlerinin birbirine yakın, çarpıklık (-0.415) ve basıklık (0.340) kat sayılarının $-1 \leq x \leq+1$ değeri arasında yer almasından dolayı dağılım normal kabul edilmiştir (Büyüköztürk, 2006).

Diğer bir varsayım olan örneklem yapısının ve maddeler arasındaki ilişkilerin yeterli olup olmadığı incelenmiştir. Örnekleme ait Kaiser-Meyer-Olkin (KMO) değeri 0.756 olarak hesaplanmıştır. KMO değerinin bir'e yakın olması verilerin faktör analizine uygun olduğunu göstermektedir (Çokluk, Şekercioğlu \& Büyüköztürk, 2018). Ölçek verilerine ait Bartlett's testi istatistiksel olarak anlamlı bulunmuştur $\left(\mathrm{x}^{2}(231)=4020.738 ; \mathrm{p}<.01\right)$. Bartlett's testinin anlamlı çıkması verilerin çok değişkenli normal dağılımdan geldiğini göstermektedir (Çokluk, \& diğ., 2018). Elde edilen sonuçlar veri setinin temel bileşenler analizi için uygun olduğunu göstermiştir. Ölçeğin yapı geçerliğini test etmek için ikinci olarak doğrulayıcı faktör analizinden (DFA) yararlanılmıştır. Bu amaçla 276 kişilik yeni bir örneklemden veri toplanmıştır. Bu örneklem grubuna ait verilere internet aracılığıyla erişilmiştir. Öğretmenler Türkiye'nin farklı illerinde görev yapan ortaokul öğretmenleridir. Yapısal model test edilmeden önce verilerin çok değişkenli normallik varsayımını karşılama durumu Mardia'nın çarpıklık ve basıklık katsayıları kullanılarak değerlendirilmiştir. Yapılan analiz sonucunda veri setinin çok değişkenli normallik varsayımını sağlamadığ görülmüştür $\left(\chi^{2}\right.$ 
$=1807.770 \mathrm{p}<0.01)$. Veri seti çoklu normallik göstermediğinden analizler asymptotik kovaryans matrisi üzerinden yürütülmüş̧ür. DFA sonuçlarının yorumlanmasında maddelerin regresyon kat sayıları ve t test anlamlılığı, uyum iyiliği testlerinin sonuçlarından yararlanılmıştır.

Ölçeğin güvenirliğini belirlemek için iç tutarlılık hakkında bilgi veren Cronbach Alfa güvenirlik katsayısı hesaplanmıştır. Ayrıca madde toplam test korelasyonundan yararlanarak maddelerin ayırt edicilikleri ve güvenirlik katsayısında yarattığı değişim incelenmiştir. Ölçeğin güvenirliğine ve geçerliğine kanıt olarak alt üst \%27'lik gruplar arası farklılaşmaya da bakılmıştır.

Araştırmanın ikinci adımı olan öğretmenlerin meslektaşlarına yönelik algıları ölçekten alınan toplam puanlar yardımıyla betimsel istatistiklerle belirlenmiştir. Ayrıca, anketteki sorularla toplanan öğretmenlerin meslektaşlarına yönelik algıları (meslektaşları hakkındaki öğrenciye, öğrenme öğretmen sürecine, milli ve evrensel değerlere, mesleki gelişime, okul aile ve toplum ilişkisine yönelik) ölçekle elde edilen bulgular ile karşılaştırmalı olarak incelenmiştir.

Öğretmen algılarının cinsiyet ve kıdeme göre farklılaşıp farklılaşmadı̆̆ını ortaya koymak için bağımsız örnekler $t$ testi ve tek yönlü ANOVA analizi yapılmıştır. Kıdem değişkeninde ANOVA sonucundaki farklılığın hangi gruplardan kaynaklandığını belirlemek amacıyla çoklu karşılaştırma testinden yararlanılmıştır. $\mathrm{Bu}$ aşamada parametrik istatistiklerin temel varsayımı olan dağılımın normalliği test edilmiş ve son hali verilen ölçekten yararlanılmıştır. Buna göre 394 kişilik örneklemden normal dağılımı bozan bireyler çıkarılarak 387'si analize dahil edilmiş ve verilerin normalliği test edilmiştir. Verilerin ortalama (42.84), mod (43.00) ve medyan (43.00) değerlerinin birbirine yakın, çarpıklık (0.555) ve basıklık (-0.476) kat sayılarının $-1 \leq \mathrm{x} \leq+1$ değeri arasında yer almasından dolayı dağılım normal kabul edilmiştir (Büyüköztürk, 2006).

\section{Bulgular}

Öğretmenlerin Meslektaşlarına Yönelik Etik Davranma Algıları Ölçeği Geçerlik ve Güvenirlik Bulguları

Araştırmanın ölçek geliştirme amacı çerçevesinde temel bileşenler analizine dayalı olarak ölçekte bulunan maddelere ait ortak varyans tablosu incelenmiş ve maddelerin en 
düşük 0.456, en yüksek 0.807 ortak varyans değerlerine sahip olduğu gözlenmiştir. Maddeler arası ilişkilerin istenilen düzeyde olduğu söylenebilir (Tabachnick \& Fidell, 2013).

Açıklanan toplam varyans tablosunu gösteren Tablo 2'ye göre öz değeri 1'in üzerinde olan 6 faktör bulunmuştur. Bu 6 faktörün toplam varyansa yaptığ1 katkının \%64.733 olduğu görülmüştür. Faktörlerin açıkladıkları varyanslar ve birbirleri arasındaki oran incelendiğinde ilk faktör yapının büyük bir kısmını temsil etmekte ve varyansın \%31.204'ünü açıklamaktadır. Diğer faktörlerin toplam varyansa katkısının oldukça azaldığı belirlemiştir.

Tablo 2 Açıklanan toplam varyanslar

\begin{tabular}{cccc}
\hline Faktör & Toplam & $\begin{array}{c}\text { Varyans } \\
\text { Yüzdesi }\end{array}$ & $\begin{array}{c}\text { Kümülatif } \\
\text { Yüzde }\end{array}$ \\
\hline 1 & 6.865 & 31.204 & 31.204 \\
2 & 2.111 & 9.595 & 40.798 \\
3 & 1.673 & 7.605 & 48.403 \\
4 & 1.363 & 6.197 & 54.601 \\
5 & 1.205 & 5.476 & 60.076 \\
6 & 1.024 & 4.657 & 64.733 \\
\hline
\end{tabular}

Yamaç birikinti grafiğindeki (Şekil 1) noktalar arasındaki eğim ve nerede plato yapmaya başladığı, ayrıca her bir faktörde açıklanan varyanslar birlikte değerlendirildiğinde yapının tek faktörlü bir yapıyı desteklediği görülmektedir. Kuramsal olarak da etik kavramı kendi içerisinde belli bir özelliği nitelediğinden geliştirilen ölçeğin tek boyutta ele alınması daha uygundur. Bununla birlikte ölçek iki ve üç boyut için de test edilmiş ancak ölçekte yer alan maddelerin istenilen boyutlara girmediği ve ölçeğin boyutlarının kuramsal olarak açıklanamamasından yapının tek boyutta olmasına karar kılınmıştır.



Şekil 1. Yamaç - birikinti grafiği 
Araştırmacılar tarafından yapının tek boyutu içerdiği kararı verildikten sonra faktör yük değerleri 0.50'nin üstünde olan maddeler analizde tutulmuştur. Madde sayısının çok olduğu ve yapıyı daha iyi ölçen maddelerle çalışılmak istenildiğinde faktör yük değerinin 0.60 ve üstü olması önerilmektedir (Tabachnick \& Fidell, 2013). Büyüköztürk (2006) ise faktör yük değerinin 0.45 ya da daha yüksek olması maddelerin yapıyı daha iyi yansıtması açısından iyi bir ölçüt olarak önermektedir. Bu sayede tek boyutlu yapıyı en iyi ölçen maddelerin ölçekte tutulmasına diğer taraftan da ölçeğin kapsam geçerliğinin kaybedilmemesine dikkat edilmiştir. Madde yük değeri 0.50 altında olan maddeler ölçekten çıkarılarak son yapı ortaya konulmuştur. Tablo 3 kalan 13 maddelik ölçeğin toplam varyansını göstermektedir. Buna göre tek faktörlü yapı varyansın \%42'sini açıklamaktadır. Tek faktörlü desenlerde açıklanan varyansın $\% 30$ ve daha fazla olması tercih edilen bir durumdur (Tavşancil, 2005).

Tablo 313 Maddelik ölçeğin açıkladığı toplam varyans

\begin{tabular}{cccc}
\hline & & Varyans & Kümülatif \\
Faktör & Toplam & Yüzdesi & Yüzde \\
1 & 5.454 & 41.953 & 41.953 \\
\hline
\end{tabular}

Elde edilen tek faktörlü veriye ait faktör yük değerleri Tablo 4 'te verilmiştir.

Tablo 4. Faktör yük değerleri

\begin{tabular}{lc}
\hline Madde & $\begin{array}{c}\text { Madde } \\
\text { Yük } \\
\text { Değerleri }\end{array}$ \\
\hline M3 & .657 \\
M7 & .763 \\
M8 & -.534 \\
M10 & .689 \\
M14 & .683 \\
M17 & .736 \\
M18 & .501 \\
M21 & .545 \\
M22 & .677 \\
M24 & .637 \\
M29 & .758 \\
M30 & .650 \\
M1 & .513 \\
\hline
\end{tabular}

Tablo 4'teki faktör yük değerleri incelendiğinde 3. maddenin olumsuz olduğu için negatif değer aldığı, maddelerin en küçük 0.501 ve en büyük 0.763 arasında değerler aldığı gözlenmiştir. 
Ölçeğin güvenirliği için test edilen Cronbach Alpha değeri 0.839 olarak hesaplanmıştır. Bu bulgu testte yer alan maddelerin iç tutarlığa sahip olduğunu diğer bir ifadeyle birbirleriyle tutarlı ve güvenilir olduğunu ortaya koymaktadır. Maddelerin ölçeğin genelinden alınan toplam puanla arasındaki korelasyonu ve Cronbach Alfa değerinin maddelerin çıkarılması durumunda nasıl değiştiği Tablo 5'te verilmiştir.

Tablo 5. Madde-toplam test korelasyonu

\begin{tabular}{lcc}
\hline $\begin{array}{c}\text { Madde } \\
\text { No }\end{array}$ & rjx & $\begin{array}{c}\text { Madde } \\
\text { Çıarıldı̆̆na } \\
\text { Cronbach } \\
\text { Alfa Değeri }\end{array}$ \\
\hline M3 & $0.690^{* *}$ & 0.814 \\
M7 & $-0.465^{* *}$ & 0.879 \\
M8 & $0.608^{*}$ & 0.820 \\
M10 & $0.607^{* *}$ & 0.821 \\
M14 & $0.650^{* *}$ & 0.815 \\
M17 & $0.457^{* *}$ & 0.830 \\
M18 & $0.472^{* *}$ & 0.829 \\
M21 & $0.576^{* *}$ & 0.822 \\
M22 & $0.499^{* *}$ & 0.828 \\
M24 & $0.671^{* *}$ & 0.813 \\
M29 & $0.526^{* *}$ & 0.826 \\
M30 & $0.471^{* *}$ & 0.830 \\
M1 & $0.578^{* *}$ & 0.823 \\
\hline$* *$ p $<0.01$ & &
\end{tabular}

Tablo 5'e göre en düşük 0.46 ve en yüksek 0.69 korelasyon değerleri gözlenmiştir. Değerlerin 0.30 'un üzerinde olması belirlenen maddelerin ölçülmesi amaçlanan yapıyla arasında orta ve üstünde korelasyonlar olduğunun göstergesidir. Bununla birlikte Cronbach Alfa değerinin madde çıkarılsa da çok fazla değişmediği görülmüştür. Ölçekte yer alan maddelerle hesaplanan güvenirlik kat sayısı istenilen düzeydedir (Tabachnick \& Fidell, 2013).

Ölçeğin geçerliğini ve güvenirliğini desteklemek için her bir maddeye ait madde ayırt edicilik gücü indeksi hesaplanmıştır. Bu amaçla veri seti toplam puana göre alt-üst \%27'lik gruplara göre incelenmiş ve karşılaştırma sonuçları Tablo 6' da verilmiştir.

Tablo 6. Alt - Üst \%27'lik Gruplar Bağımsız t Testi

\begin{tabular}{ll}
\hline \multicolumn{2}{l}{ Alt-Üst \%27'lik Gruplar Testi } \\
\hline Madde & t-değeri \\
\hline M3 & $11.133^{* *}$ \\
M7 & $13.276^{* *}$
\end{tabular}




\begin{tabular}{lc} 
M8 & $17.808^{* *}$ \\
M10 & $13.973^{* *}$ \\
M14 & $14.325^{* *}$ \\
M17 & $3.553^{* *}$ \\
M18 & $20.191^{* *}$ \\
M21 & $10.683^{* *}$ \\
M22 & $17.771^{* *}$ \\
M24 & $18.785^{* *}$ \\
M29 & $6.768^{* *}$ \\
M30 & $9.000^{* *}$ \\
M1 & $3.136^{* *}$ \\
\hline \multicolumn{2}{c}{$\mathrm{n}=104, * * \mathrm{p}<.01$}
\end{tabular}

Tablo 6 incelendiğinde alt ve üst gruplarda yer alan bireylerin etik davranma algıları ortalamalarının birbirinden her madde için anlamlı bir şekilde farklılaştı̆̆ı belirlenmiştir $(\mathrm{p}<0.01)$. Ölçekten alınan toplam puanlar üzerinden bir değerlendirme yapıldı̆̆ $ı n d a$ ise alt ve üst gruplar ortalamaları arasında anlamlı fark bulunmuştur ( $\left.\mathrm{t}_{272}=-36.88 ; \mathrm{p}<.01\right)$. Üst \%27'lik grubun ortalaması, alt \%27'lik grubun ortalamasından istatistiksel olarak yüksektir.

Ölçeğin ölçtüğü yapıyı doğrulamak için DFA analizi yapılmıştır. Analizin ilk adımında ölçekte yer alan iki maddenin hata varyanslarının 0.90'ın üzerinde olduğu belirlenmiştir. Bu iki madde sırasıyla ölçekten çıkarılarak analiz tekrarlanmıştır. DFA sonuçlarına dayalı olarak elde edilen uyum iyiliği değerleri ve kritik değerler Tablo 7'de yer almaktadır.

Tablo 7. DFA model uyum iyiliği değerleri

\begin{tabular}{|c|c|c|c|c|c|}
\hline $\begin{array}{l}\text { Uyum } \\
\text { Testleri }\end{array}$ & İyiliği & Ölçüm Modeli & Kriterler & Uyum Durumu & Referanslar \\
\hline$X^{2}$ & & 197.78 & - & & \\
\hline sd & & 44 & - & & \\
\hline $\mathrm{X}^{2} / \mathrm{sd}$ & & 4.49 & $\mathrm{X}^{2} / \mathrm{sd} \leq 0.50$ & Orta & Sümer (2000) \\
\hline RMSEA & & 0.11 & RMSEA $\leq 0.08$ & Kötü & $\begin{array}{l}\text { Jöreskog \& } \\
\text { Sörbom (1993) }\end{array}$ \\
\hline SRMR & & 0.06 & $\mathrm{SRMR} \leq 0.08$ & İyi & $\begin{array}{l}\text { Hu ve Bentler } \\
(1999)\end{array}$ \\
\hline NFI & & 0.92 & $\geq 0.90$ & İyi & Sümer (2000) \\
\hline NNFI & & 0.92 & $\geq 0.90$ & İyi & Sümer (2000) \\
\hline CFI & & 0.94 & $\geq 0.90$ & İyi & Sümer (2000) \\
\hline GFI & & 0.87 & $\geq 0.90$ & Kabul Edilebilir & $\begin{array}{l}\text { Tabachnick \& } \\
\text { Fidell (2013) }\end{array}$ \\
\hline AGFI & & 0.81 & $\geq 0.90$ & Kabul Edilebilir & $\begin{array}{l}\text { Tabachnick \& } \\
\text { Fidell (2013) }\end{array}$ \\
\hline
\end{tabular}


DFA sonucunda hesaplanan uyum iyiliği değerleri olması gereken ölçüt değerlerle karşılaştırıldığında RMSEA, GFI ve AGFI değerleri dışında diğer değerlerin yeterli düzeyde olduğu gözlenmiştir. RMSEA değerinin olması gereken kritik değer 0.10 'un biraz üstünde olduğu, GFI ve AGFI değerlerinin ise beklenen değerin biraz altında olduğu gözlenmiştir. Ancak modelde yer alan maddelerin açıkladıkları varyanslar ve toplam varyansa yaptığı katkı ve diğer geçerlik kanıtları göz önünde tutulduğunda modelin yapıyı yansıttığı kabul edilmiştir. RMSEA, GFI ve AGFI değerleri araştırmanın tartışma bölümünde tartışılmıştır.

DFA'ya dayalı regresyon katsayılarının ve $t$ değerlerinin yer aldığı sonuçlar Tablo 8'de verilmiştir.

Tablo 8. DFA modeli sonuçları

\begin{tabular}{lcll}
\hline Faktör & $\begin{array}{c}\text { Standartlaştırılmış } \\
\text { Yükler }\end{array}$ & $\mathrm{t}$ - değeri & $\mathrm{R}^{2}$ \\
\hline Teorik & & & \\
Yeterlikler & & & \\
\hline M1 & 0.69 & $11.28^{* *}$ & 0.48 \\
M3 & 0.75 & $14.04^{* *}$ & 0.56 \\
M8 & 0.65 & $12.05^{* *}$ & 0.42 \\
M10 & 0.68 & $11.81^{* *}$ & 0.46 \\
M14 & 0.69 & $15.31^{* *}$ & 0.48 \\
M17 & 0.45 & $6.50^{* *}$ & 0.21 \\
M21 & 0.62 & $12.75^{* *}$ & 0.39 \\
M22 & 0.63 & $10.58^{* *}$ & 0.39 \\
M24 & 0.71 & $15.54^{* *}$ & 0.50 \\
M29 & 0.55 & $9.87^{* *}$ & 0.31 \\
M30 & 0.49 & $5.72^{* *}$ & 0.24 \\
p<0.01 & & & \\
\hline
\end{tabular}

Tablo 8 incelendiğinde maddeler ve faktör arasındaki korelasyon katsayılarının en düşüğü 0.45 (orta düzey korelasyon) ve en yükseği 0.75 (yüksek düzey korelasyon) düzeyindedir. Hesaplanan $\mathrm{t}$ değerleri ise 11 madde için de anlamlıdır $(\mathrm{p}<0.01)$. Varyansa en çok katkı sağlayan madde 3 (0.56) iken en az katk1 sağlayan madde $17(0.21)^{\prime}$ dir.

\section{Öğretmenlerin Meslektaşlarına Yönelik Etik Davranma Algılarına Dayalı Bulgular}

Geliştirilen ölçekten yararlanılarak öğretmenlerin meslektaşları hakkındaki etik davranış algıları belirlenmiştir. Ölçekten alınabilecek en yüksek değer 55, en düşük değer ise 11'dir. Buna göre öğretmenlerin meslektaşları hakkındaki etik davranma algılarına dayalı betimsel istatistikler Tablo 9'da verilmiştir.

Tablo 9. Öğretmenlerin meslektaşları hakkındaki etik davranma algılarına ait betimsel istatistikler 


\begin{tabular}{lc}
\multicolumn{2}{l}{ Betimsel İstatistikler } \\
\hline Ortalama & 42.84 \\
Medyan & 43.00 \\
Mod & 43.00 \\
Çarpıklık & -0.555 \\
Basıklık & -0.476
\end{tabular}

Tablo 9'a göre ortalama (42.84), mod (43.00) ve medyan (43.00) değerlerinin birbirine yakın olması dağılımın normalliğine bir işaretken, değerlerin ölçekten alınabilecek yüksek değerlere yakın bulunması öğretmenlerin meslektaşlarının çoğunlukla mesleki etik davranış gösterdiğini inandığını göstermektedir.

Diğer taraftan öğretmenlere beş farklı özelliğe dayalı görüşleri sorulduğunda Tablo 10 'da yer alan bulgulara ulaşılmıştır.

Tablo 10. Öğretmenlerin meslektaşlarının mesleki etik davranışlarına yönelik gözlem sonuçları

\begin{tabular}{lll}
\hline Gözlenen Davranış Boyutu & Ortalama & SS \\
\hline Öğrenciye yönelik etik davranışlar & 4.24 & 0.830 \\
Öğrenme öğretme sürecine yönelik etik davranışlar & 4.00 & 0.896 \\
Milli ve manevi değerlere yönelik etik davranışlar & 3.89 & 0.850 \\
Mesleki gelişime yönelik etik davranışlar & 3.67 & 0.946 \\
Okul, aile ve toplum ilişkisine yönelik etik davranışlar & 3.71 & 0.767 \\
\hline
\end{tabular}

Öğretmenlerin meslektaşlarını etik davranma durumlarına göre (1-Hiçbir zaman / 5Her zaman) değerlendirmesi istendiğinde; meslektaşlarının öğrenciye yönelik etik davranışlarını $(\bar{X}=4.24)$ ve öğrenme öğretme sürecine yönelik etik davranışlarını $(\bar{X}=4.00)$ çoğu zamana yakın olarak değerlendirmektedir. Milli ve manevi değerlere $(\bar{X}=3.89)$, mesleki gelişime ( $\bar{X}=3.67)$ ve okul, aile ve toplum ilişkisine $(\bar{X}=3.71)$ yönelik etik davranışlar ise diğer davranışlara göre daha az sıklıkta gözlenmektedir. Buna göre öğretmenlerin meslektaşlarının farklı boyutlarda mesleki olarak etik davrandığını düşündüğü söylenebilir.

Araştırmanın ikinci amacına dayalı olarak öğretmenlerin algılarının cinsiyet değişkenine göre farklılaşma gösterip göstermediğine ait yapılan bağımsız gruplar $\mathrm{t}$ testi sonuçları Tablo 11'de verilmiştir.

Tablo 11. Cinsiyet değişkenine göre bağımsız grup t testi sonuçları

\begin{tabular}{|c|c|c|c|c|c|c|c|c|}
\hline \multirow{2}{*}{ Puan } & \multirow{2}{*}{ Gruplar } & \multirow{2}{*}{$N$} & \multirow{2}{*}{ Ort. } & \multirow{2}{*}{ SS } & \multirow{2}{*}{$S h_{x}$} & \multicolumn{3}{|c|}{$t$ Testi } \\
\hline & & & & & & $t$ & $S d$ & $p$ \\
\hline \multirow{2}{*}{ ÖMEDE Ölçeği } & Erkek & 186 & 41.47 & 5.8 & .42 & \multirow{2}{*}{-4.821} & \multirow{2}{*}{385} & \multirow{2}{*}{.000} \\
\hline & Kadın & 201 & 44.11 & 5 & .34 & & & \\
\hline
\end{tabular}

Tablo 11'e göre $\mathrm{t}$ testi sonucunda grupların aritmetik ortalamaları arasında anlamlı fark bulunmuştur $\left(\mathrm{t}_{(385)}=-4.821 ; \mathrm{p}<.01\right)$. Kadın öğretmenlerin ortalaması (41.47) erkek 
öğretmenlerin ortalamasından (44.11) yüksektir. Belirlenen bu üç puanlık farklılaşma küçük olsa da anlamlıdır $(\mathrm{p}<0.01)$. Kadın öğretmenler erkek öğretmenlere göre meslektaşlarının daha etik davranışlar gösterdiğini düşünmektedir.

Öğretmen algılarının kıdem değişkenine göre farklılaşma gösterip göstermediğine ilişkin tek yönlü varyans analizi (ANOVA)ait sonuçları Tablo 12' de verilmiştir.

Tablo 12. Kıdem değişkenine göre ANOVA sonuçları

\begin{tabular}{|c|c|c|c|c|c|c|c|c|c|c|}
\hline \multirow[b]{2}{*}{ Puan } & \multicolumn{3}{|c|}{ N ve $\bar{X}$ Değerleri } & \multicolumn{6}{|c|}{ ANOVA Sonuçları } & \multirow[b]{2}{*}{ Fark } \\
\hline & Grup & $N$ & $\bar{X}$ & Var. K. & KT & $s d$ & $\mathrm{KO}$ & $\mathrm{F}$ & $p$ & \\
\hline & 6-10 (1) & 77 & 36.1556 & G.Arası & 6970.356 & 3 & 2323.452 & & & $1-2,1-3$ \\
\hline Etik & $11-15(2)$ & 109 & 41.578 & G.İçi & 4825.029 & 383 & 12.598 & & & $1-4 /$ \\
\hline Algilar & $16-20(3)$ & 93 & 43.4194 & Toplam & 11795.385 & 386 & & 184.43 & .000 & $2-3.3-4$ \\
\hline Ölçeği & $21+(4)$ & 108 & 48.3889 & & & & & & & \\
\hline & Toplam & 387 & 3.17 & & & & & & & \\
\hline
\end{tabular}

ortalamaları arasında anlamlı bir fark bulunmuştur $(\mathrm{F}(3-383)=184.43, \mathrm{p}<.01)$. Bu farklılığın hangi gruplar arasında olduğunu belirlemek için çoklu karşılaştırma testinden yararlanılmıştır. Varyanslar homojen olarak dağılmadığından Dunnet C testi kullanılmıştır. Testin sonuçlarına göre bütün gruplarda düşük kıdemde olan öğretmenler, bir üst kıdemde olan öğretmenlere göre meslektaşlarının etik davranma sıklığını daha düşük olduğunu düşünmektedir. Örneğin 6-10 yıllık kıdeme sahip öğretmeler (31.16), 11-15 yıl (41.58), 16-20 yıl (43.42) ve 21-+ yıl (48.39'lık öğretmenlerin daha az sıklıkla mesleki etik davranışlar gösterdiğini düşünmektedir. $\mathrm{Bu}$ durum ayrıca öğretmenin mesleki kıdeminin artıkça meslektaşlarının daha etik davrandığını düşündüğünü ortaya koymaktadır.

\section{Tartışma ve Sonuç}

Etik alanından yapılan araştırmalar etik davranışları değerlendirmekle birlikte etik dışı davranışları veya bu davranışlara yönelik algıları ortaya koymaktadır (Altınkurt \& Yılmaz, 2011; Baloğlu, Karadağ \& Doğan, 2008; Manolova, 2011). Yapılan araştırmalar incelendiğinde öğretmenlik mesleği ile ilgili bir etik kod bütünü ortaya konulması gerekliliği ve mesleki etiğin öğretmenler tarafından uygulanabilir olması dikkat çekilen önemli bir noktadir.

Araştırma kapsamında öğretmelerin mesleki etik algılarını değerlendirmek amacıyla tek boyutlu bir yapıyı ölçen ve yapının yaklaşık yarısını açıklayabilen ölçek geliştirilmiştir. Ölçek eğitimde etik davranışlara dayalı beş özelliği içermektedir. Bunlar: öğretmenin kendine ve öğrenciye yönelik sorumlulukları, mesleki gelişimi, milli ve evrensel değerlerin aktarımı ile aile ve topluma karşı sorumluluklarıdır. Ölçeğin güvenirlik katsayısı iç tutarlık 
bakımından yüksek bulunmuş ve bu durum ölçek maddelerinin birbiri ile tutarlı olduğunu desteklemektedir (Tabachnick \& Fidell, 2013).

DFA sonucunda yapı farklı bir örneklem üzerinden tekrar test edilmiş ve uyum iyiliği değerlerinin RMSEA, GFI ve AGF değerleri dışında yeterli oldukları gözlenmiştir. RMSEA değeri yapılan araştırmalara göre örneklem sayısı ve parametre sayısından etkilenen bir değerdir. Örneklemin ve kestirilen parametre sayısının düşük olması durumunda bu değer yüksek çıkabilmektedir (Kenny \& McCoach, 2003; Kenny, Kaniskan \& McCoach, 2014). Test edilen modelin az madde içeren basit bir model, kestirilen parametre sayısının düşük (sd=44) ve grubun 276 kişi ile sınırlı olmasından dolayı bu değer istenilen düzeyde bulunmamış olabilir. Kenny, Kaniskan \& McCoach, (2014) çalışmalarında örneklem sayısı yüksek dahi olsa (1000) kestirilen parametre sayısının düşük olmasından dolayı RMSEA değerinin istenilen düzeyde olmadığını gözlemlemişlerdir. Diğer taraftan modelde GFI ve AGFI değerleri beklenen değerin biraz altındadır. Bu iki istatistik de örneklem ve kestirilen parametre sayısına duyarlı olarak değişebilmekte ve örneklem sayısına karşılık artan parametre sayısında değeri düşebilmektedir (Sharma, Mukherjeee, Kumar \& Dilor, 2005). Modelde diğer uyum iyiliği değerleri ve temel bileşenler analizinden elde edilen bulgular dikkate alınarak modelin uyumu araştırmacılar tarafından yeterli olarak kabul edilmiştir.

Öğretmenlerin mesleki etik davranışlara yönelik algıları değerlendirildiğinde öğretmenler meslektaşlarının çoğunlukla mesleki etik davranışları gösterdiğini düşünmektedir. Diğer bir deyişle öğretmenler, meslektaşlarının davranışlarını etik bulmakta, meslektaşlarını etik ilkelere uygun davrandıklarını düşünmektedir. Bu bulgu ankette yer alan özelliklere göre incelendiğinde benzer bir dağılım ortaya çıkmakta ve öğretmenler meslektaşlarının öğrenciye ve öğrenme öğretme sürecine, milli ve manevi değerlere, mesleki gelişime ve okul, aile ve toplum ilişkisine yönelik etik davranışları yeterli sıklıkta gösterdiğini düşünmektedir. Bu da eğitim ortamının gelişmesi ve öğrencilerin uygun bir eğitim ortamında öğrenim görmesi için istenen bir durumdur. Baloğlu, Karadağ ve Doğan (2008) tarafından İstanbul ili Üsküdar ilçesinde görev yapan öğretmenlerin eğitim yöneticilerinin mesleki etik davranışlarını değerlendirmesi amacıyla yapılan araştırmada, Barrett, Casey, Visser ve Headley (2012), Manolova (2011) ve Xie (2014) tarafından öğretmenlerin etik ilkelere uyma ve etik davranış gösterme düzeylerinin belirlenmesi amacıyla yapılan araştırmalarda da öğretmenlerin etik davrandıkları bulgusu elde edilmiştir. 
Öğretmenlerin, meslektaşları hakkındaki mesleki etik davranma algıları cinsiyete göre incelendiğinde kadın öğretmenler erkek öğretmenlere göre meslektaşlarının daha etik davrandığını düşünmektedir. Öğretmenlerin cinsiyetlerine göre etik davranma algılarının nasıl değiştiğini inceleyen çalışmaların bulguları farklılaşmaktadır. Örneğin Demirbolat ve Aslan (2014)'ın Sinop ilinde görev yapan ilkokul ve ortaokul öğretmenleri üzerinde yaptığı çalışmada ve Ergin (2014)'in İzmir ilinde görev yapan sınıf öğretmenleri üzerinde yaptığ1 çalışmada kadın öğretmenlerin erkek öğretmenlere göre daha etik davrandığı bulgusu elde edilmiştir. Bu araştırmalarla karşılaştırıldığında kadın öğretmenlerin hem kendileri daha etik davranmakta hem de etrafındaki meslektaşlarının daha etik davrandığını düşünmektedir. Kadın öğretmenlerin mesleki etik davranış algılarının yüksek olması onların daha duyarlı, daha iyimser ve daha esnek olmaları ile ilişkilendirilebilir. Bu bulguların tersine Altınkurt ve Yılmaz (2011) tarafından yapılan araştırmada erkek öğretmenlerin daha etik davrandıkları bulunmuştur. Yılmaz ve Altınkurt (2009) tarafından yapılan başka bir araştırmada ise cinsiyet değişkenine göre bir farklılaşma bulunamamıştır.

Öğretmenlerin, meslektaşları hakkındaki mesleki etik davranma algısı kıdem göre incelendiğinde kıdem düzeyi arttıkça öğretmenler meslektaşlarının daha etik davrandıklarını düşünmektedir. Öğretmenlerin, mesleklerinin ilk yıllarında daha istekli ve idealist davranma eğilimi fazla olabilir (Karaman, 2009). Buna bağlı olarak genç öğretmenlerin çevresindeki öğretmenlerden de beklentileri yüksek olabilir. Araştırma bulgusu, Demirbolat ve Aslan (2014) ve Ergin (2014) tarafından yapılan araştırmalar ile örtüşmektedir. Bu araştırmalarda da yüksek kıdem düzeyine sahip öğretmenler düşük kıdem düzeyine sahip öğretmenlere göre daha etik davranma eğilimindedir.

$\mathrm{Bu}$ araştırmanın sonuçları dikkate alındığında diğer araştırmacılar ölçekten yararlanarak literatürün de desteğiyle çeşitli değişkenler (okul türü, farklı eğitim düzeyi vb.) bakımından öğretmenlerin mesleki etik davranma algılarının farklılaşma durumunu inceleyebilir. Çalışmanın Denizli iliyle sınırlı olmasından dolayı, farklı örneklemlerde de incelenmesi gerektiği göz önünde bulundurulmalıdır. Çalışmanın doğrulayıcı faktör analizi farklı örneklemler üzerinde incelenip yenilenebilir. Çalışmada öğretmenlerin meslektaşlarını değerlendirmesi istenmiştir. Farklı çalışmalarda öğretmenlerin kendilerini etik açıdan değerlendirmeleri istenebilir. Bu amaçla araştırmaların ölçeği tekrar gözden geçirmesi ve yapı geçerliği gibi uygun analizleri yapması önerilir. 


\section{Kaynaklar}

Altınkurt, Y., \& Yılmaz, K. (2011). Öğretmen adaylarının öğretmenlerin mesleki etik dışı davranışlar ile ilgili görüşleri. Mehmet Akif Ersoy Üniversitesi Eğitim Fakültesi Dergisi(22), 113-128.

Aydın, İ. (2018). Eğitim ve öğretimde etik. Ankara: PEGEM Akademi.

Bakioğlu, A. (1996). Öğretmenlerin kariyer evreleri. II Ulusal Eğitim Sempozyumu (s. 19-27). İstanbul: Marmara Üniversitesi.

Baloğlu, N., Karadağ, E., \& Doğan, A. E. (2008). İlköğretim okulu yönetilcileri mesleki etik davranışları. İş Ahlakı Dergisi, 1(2), 7-26.

Barrett, D. E., Casey, J. E., Visser, R. D., \& Headley, K. N. (2012). How do teachers make judgments about ethical and unethical behaviors? Toward the development of a code of conduct for teachers. Teaching and Teacher Education, 28, 890-898. doi:10.1016/j.tate.2012.04.003

Büyüköztürk, Ş. (2006). Sosyal bilimler için veri analizi el kitabı: İstatistik, araştırma deseni, spss uygulamaları ve yorum. Ankara: Pegem Akademi Yayıncilık.

Cevizci, A. (2002). Etiğe giriş. İstanbul: Engin Yayıncılık.

Çokluk, Ö., Şekercioğlu, G., \& Büyüköztürk, Ş. (2018). Sosyal bilimler için çok değişkenli istatistik SPSS ve LISREL uygulamaları. Ankara: Pegem Akademi.

Demirbolat, A. O., \& Aslan, H. (2014). İlk ve ortaokul öğretmenlerinin etik duyarlılıklarının çeşitli değişkenler açısından incelenmesi (Sinop ili örneği). Ĕğitim Bilimleri Araştırmaları Dergisi, 4(1), 187-206.

Erdem, A. R., \& Altunsaray, M. (2016). Eğitimde niteliği belirleyen önemli bir etken: eğitim etiği. Akademik Sosyal Araştırmalar Dergisi 23, 21-30.

Ergin, Y. (2014). İlköğretim sinıf öğretmenlerinin öğretmenlik mesleği ile ilgili etik olmayan davranışlara ilişkin algılamaları (Yayımlanmamış Yüksek Lisans Tezi). İzmir: Ege Üniversitesi.

Fisher, Y. (2013). Exploration of values: Israeli teachers' professional ethics. Social Psychology of Education, 16(2), 297-315.

Hu, L.T. \& Bentler, P.M. (1999). Cutoff criteria for fit indexes in covariance structure analysis: conventional criteria versus new alternatives. Structural Equation Modeling, 6 (1), 1-55. https://doi.org/10.1080/10705519909540118

Ilgaz, S., \& Bilgili, T. (2006). Eğitim ve öğretimde etik. KKEFD(4), 199-210.

Jöreskog, K. G., \& Sörbom, D. (1993). Lisrel 8: Structural equation modeling with the SIMPLIS command language. Scientific Software International.

Karaman, T. (2009). Öğretmenlerin öğretme tutkusunun sürekliliğini etkileyen faktörlerin incelenmesi. (Yayımlanmamış Doktora Tezi). İstanbul: Marmara Üniversitesi

Karasar, N. (2000). Bilimsel araştırma yöntemi (10. Baskı). Ankara: Nobel Yayın Dağıtım.

Kenny, D. A., Kaniskan, B., \& McCoach, D. B. (2015). The performance of RMSEA in models with small degrees of freedom. Sociological Methods $\mathcal{E}$ Research, 44(3), 486-507. http://dx.doi.org/10.1177/0049124114543236 
Kenny, D. A., \& Mc Coach, D. B. (2003). Effect of the number of variables on measures of fit in structural equation modeling. Structural Equation Modeling, 10(3), 333-351.

Key, S., \& Popkin, S. J. (1998). Integrating ethics into the strategic management process. Doing Well by Management Decision, 36(5), 331-338.

Manolova, O. (2011). Mesleki etik ilkelere ilişkinTtürkiye ve Moldova'daki ilköğretim okulu öğretmenlerinin görüşleri. Ankara: Ankara Üniversitesi (Yayınlanmamış Doktora Tezi).

Milli Eğitim Bakanlığı [MEB]. (2005, Eylül). Etik. Mart 18, 2019 tarihinde MEB-Etik Komisyonu: http://etik.meb.gov.tr adresinden alındı

Milli Eğitim Bakanlığı [MEB]. (1973, Haziran). Milli eğitim temel kanunu. Mart 28, 2019 tarihinde Mevzuat: http://www.mevzuat.gov.tr/Mevzuat/Metin/1.5.1739.pdf adresinden alınd 1

Santa Clara University. (2015, Ağustos 1). A Framework for ethical decision making. Mayıs 23, 2019 tarihinde Markkula Center for Applied Ethics: http://www.scu.edu/ethics/practicing/decision/framework.html adresinden alındı

Sharma, S., Mukherjee, S., Kumar, A., \& Dillon, W. R. (2005). A simulation study to investigate the use of cutoff values for assessing model fit in covariance structure models. Journal of Business Research, 58(7), 935943. https://doi.org/10.1016/j.jbusres.2003.10.007

Sümer, N. (2000). Yapısal eşitlik modelleri: Temel kavramlar ve örnek uygulamalar. Türk Psikoloji Yazıları, 3(6), 49-73.

Sünbül, A. M. (1996). Öğretmen niteliği ve öğretimdeki rolü. Ĕ̆itim Yönetimi, 2(1), 597-607.

Tabachnick, B. G., \& Fidell, L. S. (2013). Using multivariate statistics. London: Pearson Education.

Tunca, N., \& Sağlam, M. (2013). İlköğretim öğretmenlerine yönelik mesleki değerler ölçeğinin geçerlik ve güvenirlik çalışması. Eğitim Bilimleri Araştırmaları Dergisi, 3(1), 140-164.

Xie, O. (2014). Research on the present situation of primary and secondary teachers' professional ethics in China. Canadian Social Science, 10(6), 72-77.

Yılmaz, K., \& Altınkurt, Y. (2009). Öğretmen adaylarının mesleki etik dışı davranışlar ile ilgili görüşleri. İş Ahlakı Dergisi, 2(4), 71-88. 